\title{
George Huntington: the man behind the eponym
}

\author{
Nadja Durbach, Michael R Hayden
}

\begin{abstract}
George Huntington first encountered patients with the disease subsequently given his name at the age of 8 while accompanying his father and grandfather on their medical rounds. In 1872, in his twenty-first year, he described this disease so accurately and succinctly that the disease was later named after him. We have explored, through contact with previously unpublished family records and documents, the personal factors which helped George Huntington to make this observation and also investigated why this remains his sole contribution to medical research. We show by documenting his precise examinations of nature that he had profound powers of observation. Furthermore his decision not to pursue medical research was based on a commitment to patient care and a belief that he could make a greater contribution through the practice of primary care medicine rather than the pursuit of research.
\end{abstract}

(f Med Genet 1993;30:406-9)
In 1933, Katharine Huntington Hutchison, daughter of George Huntington, wrote:

Our family is only an average family, with the usual routine of births and deaths, joy and sorrow, laughter and tears. I do not recall any soaring flights of great brilliancy, neither were there any heartbreaking tragedies; just an average, commonplace American family ...

For those afflicted with Huntington's disease this description is far from accurate, for George Huntington did have one "flight of great brilliance" when on 15 February 1872 he presented an essay to the Meigs and Mason Academy of Medicine at Middleport, Ohio entitled 'On Chorea'. ' At the age of 21, George Huntington succeeded in identifying and describing the discrete form of chorea which today bears his name so completely and succinctly that it prompted William Osler to declare:

In the whole range of descriptive nosology there is not, to my knowledge, an instance in which a disease has been so accurately and fully delineated in so few words. No details were given; the original cases were not even (nor have they been) described, but to Huntingdon's [sic] account of the symptomatology no essential fact has been added. ${ }^{2}$
Department of Medical Genetics, University of British Columbia, 416-2125 East Mall, Vancouver, BC V6T 1Z4, Canada. N Durbach

M R Hayden

Correspondence to Dr Hayden.

Received 2 December 1992. Accepted 7 December 1992.

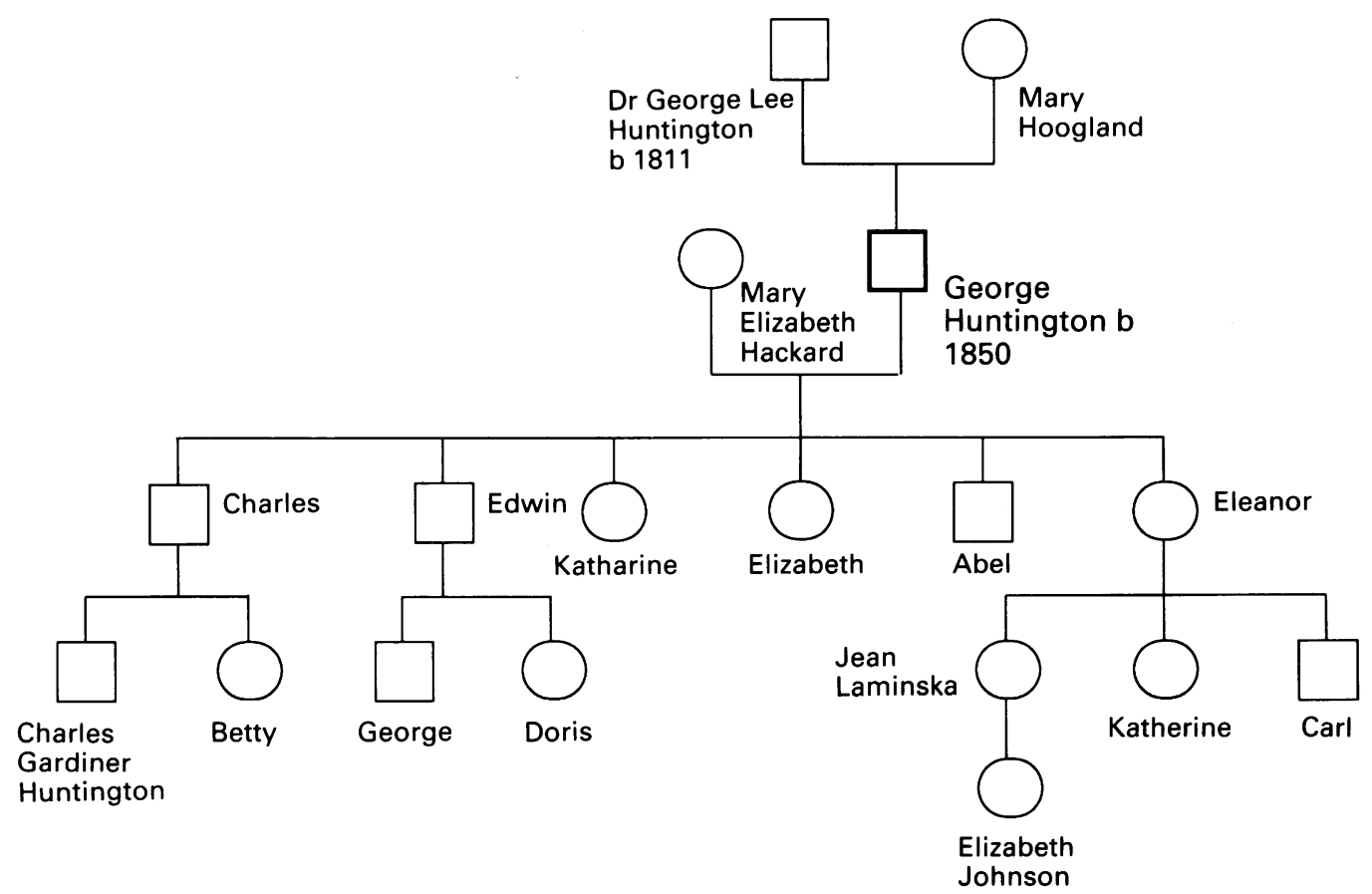

Figure 1 Family tree of George Huntington showing his six children and grandchildren. 
Despite this important achievement, Huntington remained virtually unknown to those who lived outside his community, for he spent the rest of his career as a general practitioner. ${ }^{3}$ Today this seems surprising for a young man in this situation could have pursued a career in medical research. Yet for George Huntington this was not a desirable career choice, partly because of the time in which he lived and partly because of his nature. We have explored previously unpublished diaries and biographical sources to gain insights into what personal qualities facilitated his accurate description of HD and what factors influenced him to pursue his chosen career path.

\begin{abstract}
Methods
All relevant published biographical sources available on George Huntington were read, as were numerous other articles on the history of Huntington's disease. In addition the unpublished memoirs of Katharine Huntington Hutchison, daughter of George Huntington, were read in their entirety, family photographs were consulted, and all available sketches and drawings by George Huntington were examined. Several descendants of George Huntington were contacted by mail including Charles Gardiner Huntington, grandson of George Huntington, Doris Huntington, granddaughter, Jean Lominska, granddaughter, and Elizabeth Johnson, great granddaughter, who was contacted in person (fig 1). These people provided invaluable help and information regarding the life and work of George Huntington.
\end{abstract}

\section{Results and discussion}

George Huntington began making the rounds of the hospital in the Long Island community of East Hampton where he lived at a very young age. Katharine Huntington Hutchison, his daughter, recalls:

Once, when Father was a small boy, he was going the round of calls with his father when one of the neighbours stopped them for a chat. 'Well, Doctor, what are

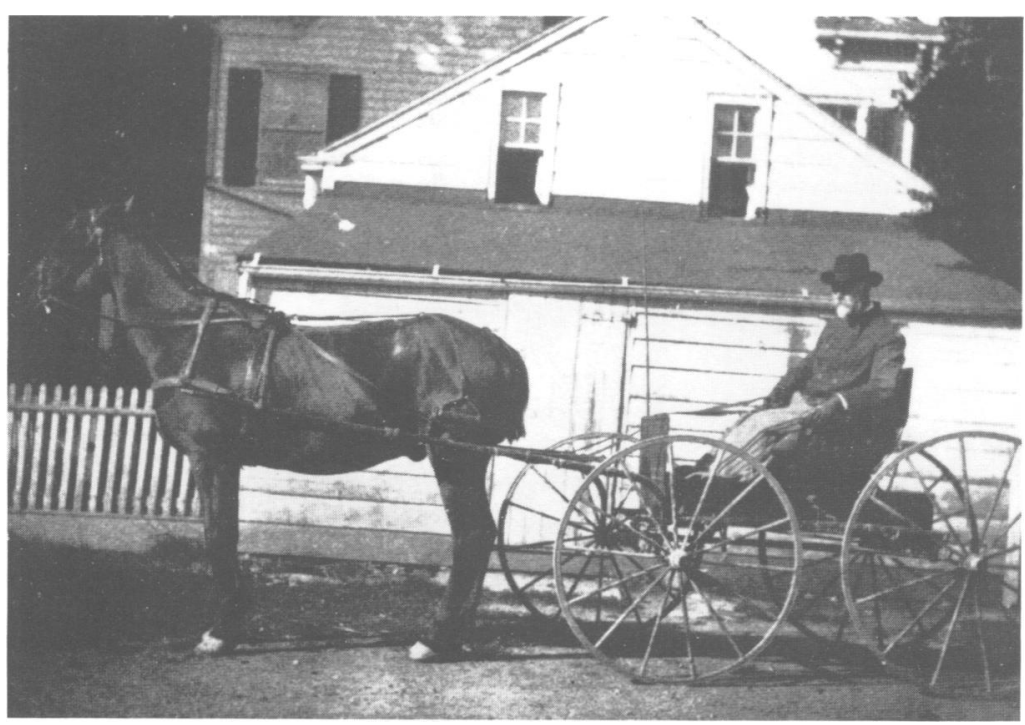

Figure 2 George Huntington was a family physician and did his rounds in his horse driven carriage. you going to make of George? A doctor?' 'Not if I can help it', said Grandfather.

But George did become a doctor, graduating from the College of Physicians and Surgeons in New York in 1871 with a thesis on opium ${ }^{4}$; shortly thereafter he wrote his paper 'On Chorea' which was edited by his father, whose notes can still be seen on the original manuscript. $^{5} \mathrm{He}$ began to practice medicine in Pomeroy, Ohio on the advice of his cousin's (Fanny Gardiner) husband Reverend Maples, who felt this represented a good opening for a young doctor. In Pomeroy he met Mary Hackard whom he married, and together they moved to La Grange, New York (fig 1).

Huntington himself dates his interest in chorea to an event which occurred at the age of 8. He recounts:

Over fifty years ago, in riding with my father on his professional rounds, I saw my first case of 'that disorder', which was the way in which the natives always referred to the dreaded disease. It made a most enduring impression upon my boyish mind, an impression every detail of which I recall today, an impression which was the very first impulse to my choosing chorea as my virgin contribution to medical lore. We suddenly came upon two women, mother and daughter, both tall, thin, almost cadaverous, both bowing, twisting, grimacing. I stared in wonderment, almost fear. What could it mean? My father paused to speak with them and we passed on. Then my Gamaliel-like instruction began; my medical instruction had its inception. From this point on my interest in the disease has never wholly ceased. ${ }^{5}$

Although his interest in Huntington's disease may never have ceased, his research did. Huntington pursued his study of the disease no further, and yet if one places Huntington in his historical milieu and examines his private self, one comes to see why being a 'country doctor' was a fulfilling and natural career choice for him (fig 2).

Russell N DeJong said of George Huntington: "Huntington was a general practitioner of medicine; his major interests were his patients and their problems. No faculty appointments came his way, nor did he perform any significant research." 5 To understand why Huntington did not pursue a career in research one must know something of medical research at that time. ${ }^{6}$ It is clear that "there was no systematic research and very little research of any type during the first century of American medicine (1776-1876)". ${ }^{7}$ In contrast to most research being centred in institutions of learning as it is today, in the late nineteenth century, medical authority was located in the individual practitioner. From the Civil War to the First World War, most physicians were general practitioners and medicine was more devoted to the art of health care rather than to the search for knowledge. ${ }^{8}$ To place George Huntington in his historical context is to recognise that he did not turn his back on a promising research career, but rather followed the path of the majority of those with a medical degree, choosing to practice his art rather than engage in scientific pursuits.

The explanation for Huntington's choice does not end here, however; much must be attributed to Huntington's private self. Huntington's view of his contribution to medicine 
seems vastly different from how we see it today. He referred to his acclaim as an "unsought, unlooked for honor" and spoke of Huntington's disease as his contribution to "medical lore". 1 The concluding words of "On Chorea' seem to reflect his attitude towards his discovery:

I have drawn your attention to this form of chorea gentlemen, not that I considered it of any great practical importance to you, but merely as a medical curiosity, and as such it may have some interest.

For Huntington, this was no landmark in medicine, but was rather a 'curiosity', something of interest but of little significance.

Why did Huntington himself relegate his medical contribution to such a marginal position? The answer to this is to be found not only in the modesty of the man, but in his recognition that identifying this discrete form of chorea does little in itself to cure the illness. In the late nineteenth century medical genetics was in its infancy, and pursuing a cure for a hereditary disease such as Huntington's disease seemed an unrealistic endeavour. Even two generations later, Charles Gardiner Huntington, George's grandson, expresses helplessness in the face of HD.

I have known people suffering with Huntington's disease, and when I saw them, I knew what it was my grandfather felt. Especially, I knew that feeling of there being so little we could do for them.

Aside from the obvious limitations of knowledge concerning genetics, Huntington pursued a career in family practice because it suited his personality. Described by many as a caring, gentle, and humorous man, he seemed to feel at ease in a small community playing the many roles a country doctor needs to assume. Katharine Huntington Hutchison said of her father:

He ushered them into life, he often closed the eyes of the dying, he read the burial service and baptized infants; he was with them in their joys and sorrows-a beloved physician. For twenty-five years, come snow or blow, or sleet or dust, Father jogged about among them until failing health drove him into other scenes and life.
An avid hunter and fisherman, Huntington's great love of nature kept him in the country (figs 3 and 4). A keen observer, Huntington was greatly interested in plants and animals as well as star gazing. This love of nature coupled with his chronic asthma suited Huntington to a life far away from the urban city and thus the few centres of research. And yet despite his poor health, Huntington was able to maintain a sense of humour as his daughter recounts:

. . our lives were overshadowed by Father's poor health-his attacks of asthma, his hay fever always to be reckoned with. . . . One fall, he rigged himself a respirator-it was made of pasteboard and gauze-a comical looking beak effect which he tied over his nose and mouth to keep out the dust-not unlike the 'schnozzle' noses the children now wear. He did look funny, and one day one of his patients, Mrs Losee, met with him, 'Ha, ha! Doctor! $\mathrm{Ha}$, ha! What are you wearing that thing on your nose for, Doctor?' 'Ha, ha!' replied Father, 'To keep it from poking into other folks' business, $\mathrm{Ha}$, ha!'

His family life as well must be seen as a factor in his decision to pursue general practice. Huntington's pen and ink sketch of himself attempting to read a medical journal while his five children clamber around him shows the difficulty of doing any serious research in a family with many children (fig 5).

But perhaps the most telling and poignant reason for his choosing to pursue general practice lies in the fact that George Huntington's life long desire, as he communicated to his daughter Katharine in the last year of his life, was to be an artist. Katharine Huntington Hutchison recalls:

Father was an artist at heart, and with no training whatever in drawing or painting was able to put his love of nature on paper. I remember him coming home from a day's business in 'town' with an etching. His eyes were alight, he was so elated over owning it, though it cost much more than his slender purse could afford. . . . I remember one time when he came back from a trip to New York and the Museum of Art, how delighted he was over a conversation with some fellow spirit, and their agreement over the impossible colouring in one of Turner's masterpieces.

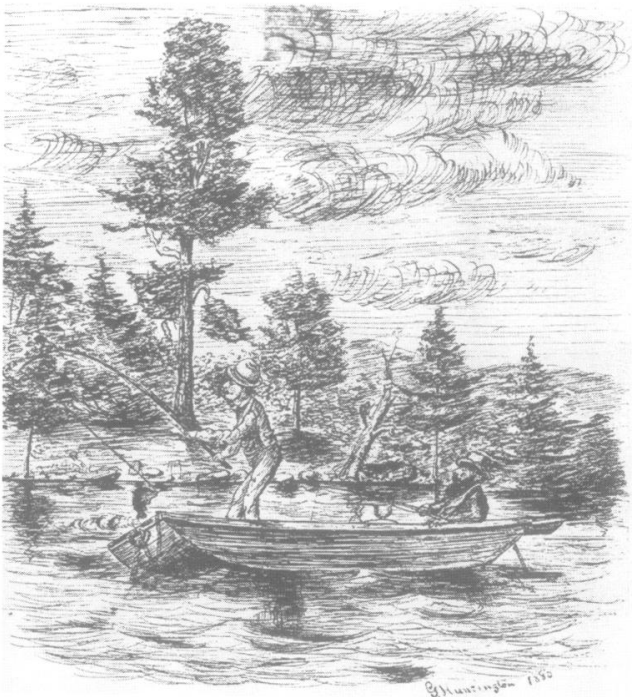

Figure 4 George Huntington was a keen fisherman as seen in this sketch of a fisherman reeling in a salmon in 1880 . 


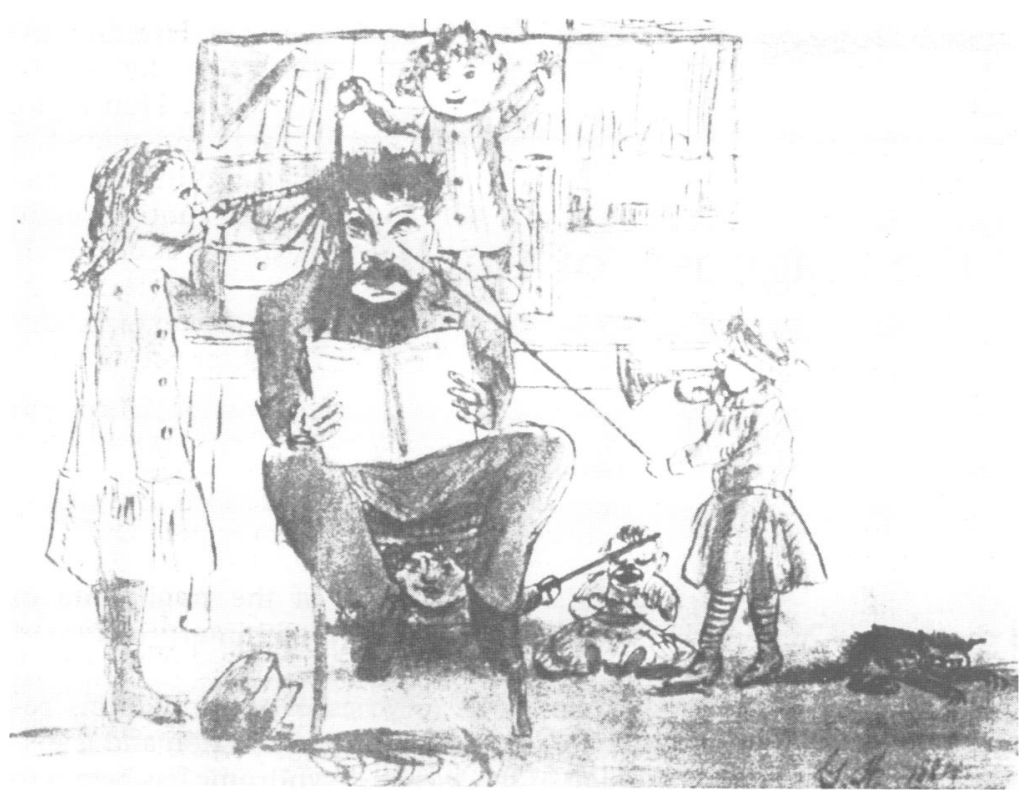

Figure 5 A pen and ink sketch of George Huntington attempting to read a medical journal while his five children climb all around him.

Huntington made many pen and ink sketches and a few paintings, all of which remain with the family today. His love of art bound him to the natural world, and thus he also viewed the practice of medicine as an art.

These drawings and paintings expose a talent for observation, for the appreciation of detail (fig 6), and it is this observational skill which may have allowed Huntington to de-

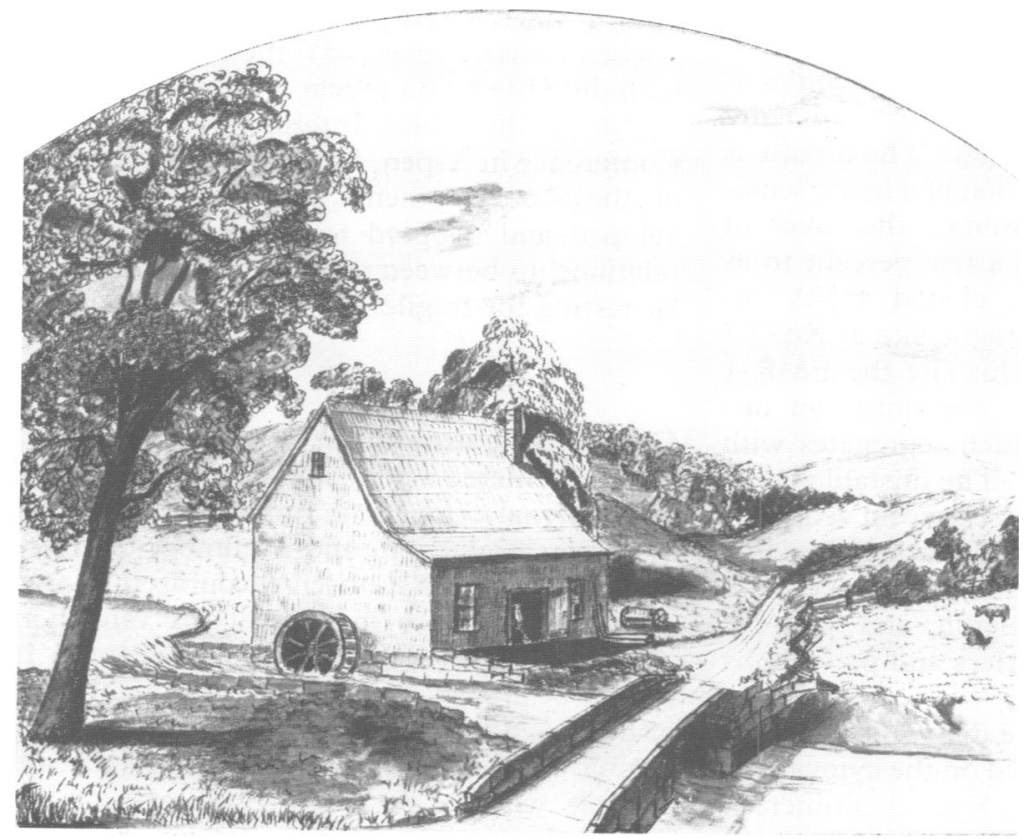

Figure 6 George Huntington had significant powers of observation as witnessed in his detailed drawings of the world around him. scribe Huntington's disease so accurately. Doris Huntington, granddaughter of George Huntington, has said, "Grandfather's powers of observation, evidently, were strong when it came to the natural world around him. I often have wondered whether this trait, passed on to his children and grandchildren, led him to observe something special about those affected by the 'chorea' he later described." Katharine Huntington Hutchison echoes this sentiment as she recalls her father's love of the natural world:

One great joy was to be allowed to go on Father's round of calls with him, and during those rides he inculcated in us his own love of nature and gave us the benefit of his keenly observant eye. It was he who told us the names of many different stars, taught us about the trees and the birds and the wild flowers, to know the scientific name of Joe Pye Weed is Eupatorium purpureum, to watch for glacial scratches in the rock. In other words, he trained us to go through life with our eyes open.

It is apparent that George Huntington went through life with his eyes wide open, observing and recording every detail of the natural world around him. This attention to careful observation must be seen as a key factor in Huntington's ability to describe so accurately and succinctly the disease that bears his name.

Despite the fact that he did not pursue any research, George Huntington made a profound contribution to medicine. In the words of his grandson, Huntington did more than merely describe and isolate this form of chorea, "he gave people with the disease a humanity they'd never had before".

We thank the members of the Huntington family, especially Charles Gardiner Huntington, Doris Huntington, Jean Lominska, and Elizabeth Johnson for their invaluable support and help in examining the life of George Huntington. The useful comments of members of our laboratory are appreciated. Dr M R Hayden is an established investigator of the BC Children's Hospital. This work is supported by grants from the MRC of Canada.

1 Huntington G. On chorea. Med Surg Rep 1872;26:317-21.

2 Osler W. Remarks on the varieties of chronic chorea, and a report upon two families of the hereditary form, one with autopsy. F Nerv Ment Dis 1893;18:97-8.

3 Hayden MR. Reflections on the history of Huntington's chorea. Trends Neurosci 1983;6:122-6.

4 Barbeau A. The understanding of involuntary movements: an historical approach. $尹$ Nerv Ment Dis 1958;127:469-89. 5 DeJong RN. George Sumner Huntington. In: Haymarer ed. Founders of neurology. Illinois: Charles $C$ 1953:305-8.

6 Marks G, Beatty WK. The story of medicine in America. New York: Scriber and Sons, 1973:273.

7 Bordley J III, McGehee Harvey A. Two centuries of American medicine 1776-1976. Philadelphia: Saunders, 1976:77.

8 Cassedy JH. Medicine in America. Baltimore: Johns Hopkins University Press, 1991:67.

9 Brody IA, Wilkins RH. Huntington's chorea. Arch Neurol 1967;17:331. 